\title{
Abundance, recruitment, and shell growth of the exotic mussel Limnoperna fortunei in the Río de la Plata (Argentina)
}

\author{
Fernando Spaccesi
}

\begin{abstract}
Background: Since its accidental introduction in 1991, - Limnoperna fortunei has spread throughout the del Plata basin becoming established as a new non-indigenous freshwater bivalve in South America.

Results: I compared its population dynamics between two - sites in the Río de la Plata Estuary at Bagliardi Beach (freshwater) and Punta Indio Beach (saltwater-influenced) $90 \mathrm{~km}$ to the south, by monthly sampling of mussel conglomerates on hard substrate - during low tides for 1 year and observed significant variability over space and time. Punta Indio exhibited lower abundances of recruits $(<1 \mathrm{~mm})$ and post-recruits along with a larger adult size than those at Bagliardi Beach. The extent of air exposure appeared to be a major constraint regulating mussel densities in these areas. The high recruitment at Bagliardi Beach indicated continuous reproduction that was positively correlated with temperature changes. Recruits survived in low water temperatures $\left(10.7^{\circ} \mathrm{C}\right)$. The species' abundance had stabilized by several years after the invasion. In contrast, at Punta Indio, settlement availability depended on critical environmental conditions. The multivariate analysis- identified a combination of physicochemical variables, of temperature, dissolved solids, and oxygen saturation, that best explained the golden mussel's abundance. Possible north-to-south larval dispersal may have influenced recruitment patterns. The von Bertalanffy growth model suggested that populations consisted of three principal cohorts at both Bagliardi Beach and Punta Indio: $L t=18$ to $20 \mathrm{~mm}$ (first-year growth) and $L_{\text {inf }}=30 \mathrm{~mm}$. Mussels of Punta Indio showed faster growth rates $(k)$ than those at Bagliardi Beach, probably because of wave exposure and low population densities.

Conclusions: This work provides specific information that complements our present knowledge of the ecology of this invasive mollusk. Further studies will be essential to gain an understanding of the population dynamics and the way in which the golden mussel reacts to stressful conditions.
\end{abstract}

Keywords: Biological invasion; Brackish water; Hard substrate; Population dynamics; South America

\section{Background}

Biologic invasions are defined as the geographical expansion of a species into a region that it had not previously occupied and begin with the arrival of a founding population followed by establishment of those individuals and their regional dispersal, subsequent colonization, and integration into previously uninhabited areas (Vermeij 1996). Aquatic environments are highly vulnerable to accidental and deliberate introductions of non-indigenous species. Alien species can change the structure of communities,

Correspondence: pachamo@yahoo.com

Laboratorio de Bentos, Instituto de Limnología Dr. Raúl A Ringuelet (ILPLA)-CCT CONICET-UNLP, Boulevard 120 y 62, CC 712, La Plata, Buenos Aires CP 1900, Argentina produce significant alterations in biodiversity, modify primary production and nutrient cycles, and eliminate native species (Moyle and Light 1996, Grosholz 2002). In freshwater, estuarine, and marine ecosystems, the transfer of non-indigenous species has been increasing for several decades due to the development of aquaculture, and particularly through the vehicle of ballast water of ships as a result of expansion of trade and transport (Wasson et al. 2001). Several species of mollusks have been widely introduced outside their native region by these means and have subsequently become dispersed through the movement of pelagic or planktonic larvae, e.g., the gastropod Pomacea canaliculata (Lamarck 1822) was illegally introduced into Taiwan from South America in 1979 (Wu et al. 2011),

\section{实}


while the bivalve Mytilus galloprovincialis (Lamarck 1819), although a native of the Mediterranean, has successfully invaded many marine coasts throughout the world (Suchanek et al. 1997, Bownes and McQuaid 2006). The golden mussel L. fortunei (Dunker 1857) is a freshwater Mytilidae and a native of Southeast Asia (Morton 1973). This species was discovered in 1991 in the Río de la Plata Estuary of Argentina and thereafter rapidly became a pest species in the region (Pastorino et al. 1993).

The Río de la Plata is a plains estuary with the Paraná and Uruguay Rivers being its principal tributaries. Three main zones are recognized on the basis of fluvial-marine characteristics (geologic, hydrologic, and biologic): internal $(0.2$ to $0.5 \mathrm{psu})$, intermediate $(0.3$ to $5 \mathrm{psu})$, and external zones (5 to $25 \mathrm{psu}$; Figure 1). L. fortunei has spread from the temperate zone of this estuary by means of the Paraná, Paraguay, and Uruguay rivers into most of the del Plata basin (the second largest hydrographic basin in South America next to the Amazon) to reach as far as subtropical freshwater areas of Bolivia and Brazil (Boltovskoy et al. 2006). The golden mussel has also invaded the Lagoa dos Patos in southern Brazil (Mansur et al. 2003). The life cycle of this exotic species includes two principal stages: (a) planktonic larvae and (b) benthic juveniles and adults. The benthic stage is characterized by an epifaunal lifestyle as a result of the strong attachment of the byssus onto hard natural and artificial substrates (Boltovskoy et al. 2006). This species exhibits characte- ristics similar to those of the zebra mussel Dresissena polymorpha (Pallas 1771), which was introduced in North America in the 1980s from freshwater ports of Eurasia. Both of these invasive species are characterized by high fecundity, a pronounced capacity for dispersion, rapid growth and colonization, effective occupation of vacant niches, dense aggregations, and the ability to live in polluted sites (Darrigran et al. 1999, Cataldo and Boltovskoy 2000). L. fortunei is associated with biofouling problems because it attaches to water-intake structures and filters in water-supply systems, industrial plants, and hydroelectric stations (Cataldo et al. 2003). Impacts of this mussel on natural ecosystems have still not been fully investigated; but $L$. fortunei was thus far shown to modify the organic matter of the environment, oxygenate the water (Boltovskoy et al. 2006), attach to other mollusk species so as to hinder the displacement and mobility of those hosts (Mansur et al. 2003), increase the diversity and abundance of many other benthic organisms (Spaccesi and Rodrigues Capítulo 2012), and serve as food for several types of fish (Sylvester et al. 2007).

Valuable research on the population dynamics of $L$. fortunei was carried out; recruitment, settlement patterns, abundances, age structures, and individual growth were studied in Southeast Asia by Morton (1977), Magara et al. (2001), and Nakano et al. (2011), and in South America by Boltovskoy and Cataldo (1999), Mansur et al. (2003), Maroñas et al. (2003), and Oliveira et al. (2011). No

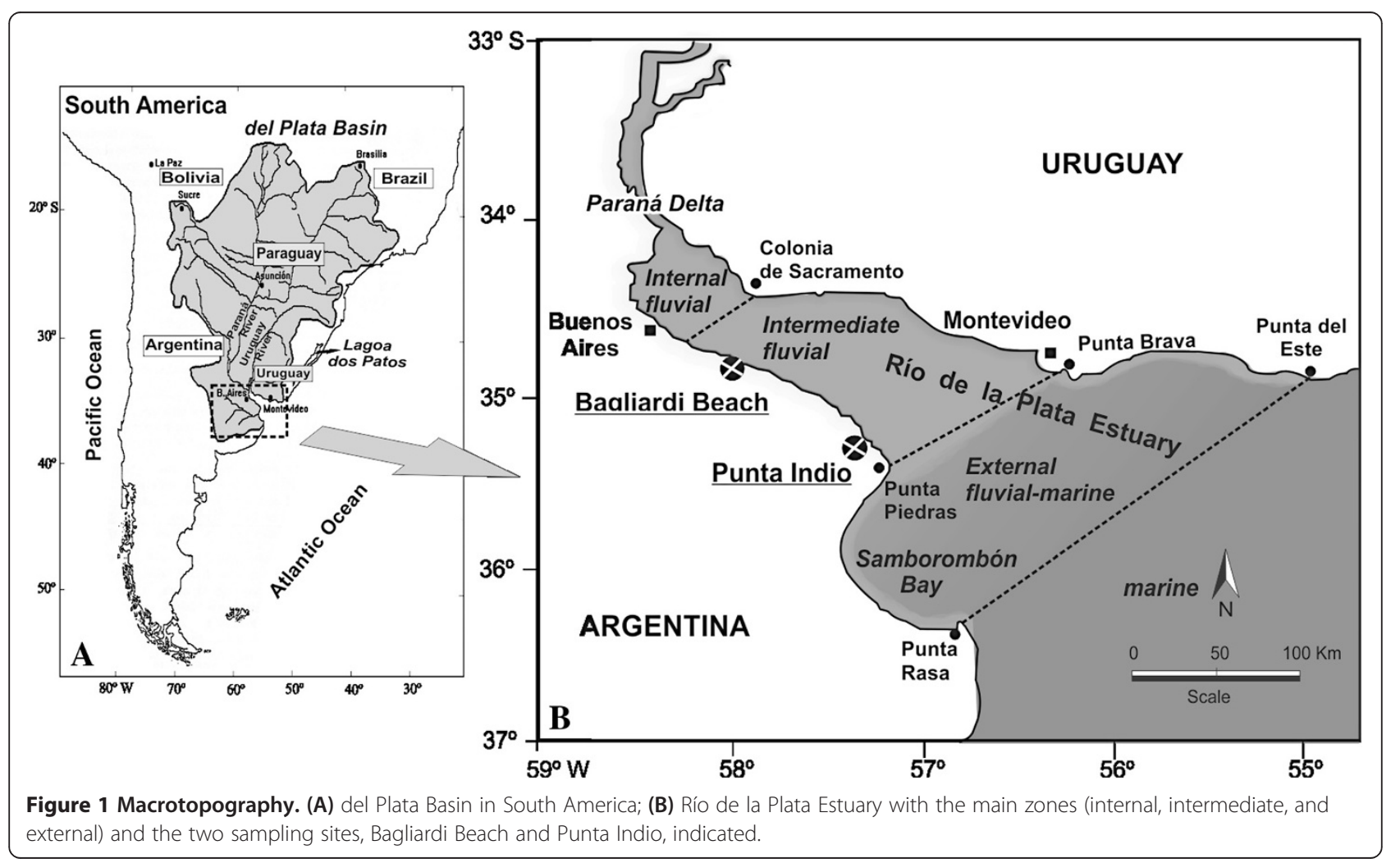


studies on the population dynamics of $L$. fortunei in the southernmost extension of its distribution in South America and/or under conditions of natural environmental stress; however, have as yet been undertaken.

The present investigation was conducted with the hypothesis that the population dynamics, i.e., recruitment, abundance, and individual growth, of the golden mussel would be more unstable in an estuarine area (the external zone) of the Río de la Plata than in a freshwater region, because of the high level of environmental stress and large physicochemical variations that occur in the outer zone. The objectives of the work were thus to (a) analyze abundances of $L$. fortunei at two sites within the intermediate zone of Río de la Plata Estuary, one bordering the internal and the other the external zone, (b) compare frequency distributions of individual sizes (i.e., shell length), (c) determine growth curves of each population, and (d) describe the effects of environmental variables on the mussel's population structure and dynamics.

\section{Methods}

\section{Study area}

The Río de la Plata Estuary is ca. 323-km long and 230-km wide at its mouth, and has a mean flow of $23,000 \mathrm{~m}^{3} / \mathrm{s}$ and a semidiurnal microtidal regime (ranging 0.3 to $1 \mathrm{~m}$ ) that exhibits diurnal inequalities and asymmetries (Bazán and Arriaga 1993, Guerrero et al. 1997). Two sites in the intermediate zone of the estuary were chosen: a northern one at Bagliardi Beach $\left(34^{\circ} 55^{\prime} \mathrm{S}, 57^{\circ} 47^{\prime} \mathrm{W}\right)$, where the golden mussel was initially found in 1991 and where previous research on the population ecology was conducted, and a southern one at Punta Indio $\left(35^{\circ} 16^{\prime} \mathrm{S}, 57^{\circ} 13^{\prime} \mathrm{W}\right)$, the southernmost limit of the species' distribution in South America and an area that experiences environmentalsalinity stress. Both sites were also chosen because of the accessibility to the estuary's shore. The macrotopography is similar between sites, and they are located $90 \mathrm{~km}$ apart (Figure 1). At both sites, hard substrates were scarce, but a few compact granite rocks were present that had irregular surfaces and were similar in size (ca. $18,000 \mathrm{~cm}^{3}$ ), either stacked at Bagliardi Beach or scattered over a smooth slope at Punta Indio. The scarcity of hard natural substrates in the Río de la Plata Estuary had previously prevented the development of sessile or sedentary fauna until human activities began to change the coastline through creating docks and placing boulders. The latter rocks are usually used for shoreline defense and were installed by the authorities to prevent flooding under extraordinary tidal and wind conditions. Hard substrates are directly influenced by the sun (insolation) during low tides and are exposed to the mechanical action of waves at high tides (Wells and Daborn 1997). Waves are usually small (average height, $0.31 \mathrm{~m}$ ) in the intermediate zone of the estuary, while the largest ones occur in the external zone and the smallest ones in the inner zone (Guerrero et al. 1997). Bagliardi Beach is surrounded by a long stretch of soft sand and silt, whereas the beaches around Punta Indio are composed of mud and silty clay. The hard substrates at both sites are stable and occupied by $L$. fortunei; it is nonindigenous and forms monospecific mussel beds. The barnacle Balanus improvisus (Darwin 1854) is the other sedentary species that is present at Punta Indio, although in much lower abundances than the golden mussel (pers. observ.); this beach constitutes the northern limit of the distribution of B. improvisus along the Argentine coastline. This barnacle was more frequently found attached to $L$. fortunei shells than in continuous mats on the substrate. The rocky littoral zone of the Río de la Plata Estuary does not display the classical zonation scheme characterized by different sessile species exhibited by several estuaries and marine ecosystems (Stephenson and Stephenson 1949), principally because of the river's extremely low slope and extensive beaches along its banks (Wells and Daborn 1997). The Río de la Plata Estuary has an intertidal region that is essentially defined by the respective values for mean low water, mean tidal range, and mean tide level of 0.52 , 0.52, and $0.79 \mathrm{~m}$ at Bagliardi Beach, and 0.48, 0.68, and $0.85 \mathrm{~m}$ at Punta Indio (SHN 2001); these two sites are located at the borders of the estuary's intermediate salinity zone of 0.3 to 5 psu (see "Background").

\section{Sampling design}

From April 2001 to March 2002 at both Bagliardi Beach and Punta Indio, monthly samples were removed from the hard underwater substrates (rocks) that were accessible during low tide (spring tide) between the mean tide level and mean low water. Neither site had accessible boulders at a low water of $0.13 \mathrm{~m}$ or below nor at a mean high water of $1.04 \mathrm{~m}$ at Bagliardi Beach or $1.16 \mathrm{~m}$ at Punta Indio. Field sampling was conducted at 10:00 to $12: 00$ at Punta Indio, and at 14:00 to $16: 00$ at Bagliardi Beach on the same day by following the course of the low tide as it moved from south to north. In total, five samples were taken at random at each site per month and in directions both parallel and perpendicular to the shoreline. Thus, 120 samples (5 samples $\times 2$ sampling sites $\times 12$ months) were analyzed. Samples were taken from within an open $25-\mathrm{cm}^{2}$ wooden square frame placed on the flat surface of a boulder in an area entirely covered by mussels. The squares were placed ca. $3 \mathrm{~m}$ from each other on a total of ca. $81 \mathrm{~m}^{2}$ of a rocky platform at each site. After removing all individuals from within each square with a spatula, samples were placed in individual plastic bags, labeled, and taken to the laboratory for processing.

The following physicochemical variables of the water were measured in situ with portable meters: temperature in degree Celsius (with a digital thermometer), dissolved 
oxygen (DO) in milligrams per liter (Crison Oxi 330, Barcelona, Spain; WTW, Weilheim, Germany), oxygen saturation as a percent (Crison Oxi 330), pH (Hanna, Oklahoma, USA), total dissolved solids (TDS) in milligrams per liter (Corning, New York, USA), and conductivity in micro Siemens per centimeter (Corning); the last two parameters are considered indicators of salinity (APHA 1998).

In the laboratory, samples of $L$. fortunei were rinsed with running water in a sieve (containing a 60- $\mu \mathrm{m}$ wire gauze). Individuals of greater than $1 \mathrm{~mm}$, which included juveniles and both prereproductive and reproductive adults, were separated with forceps or by hand from sediment particles and then counted, and the shell length was measured (the maximum anterior-posterior axis) with digital Vernier calipers. Sediment particles retained in the sieve were observed, and recruits (of less than $1 \mathrm{~mm}$ ), i.e., early juveniles, were counted under a binocular magnifying glass. These recruits were ready to attach to a hard substrate as evidenced by the welldeveloped foot and the presence of a shell (Cataldo and Boltovskoy 2000).

\section{Data analysis}

The five samples each month were averaged, and the following population variables were measured: abundance as individuals (ind.) per square meter and shelllength frequency as a percent (after separation into 1-mm intervals). All physical and chemical variables were $\log _{10}$ $(X+1)$-transformed, except for $\mathrm{pH}$; whereas abundance data were converted into square roots to achieve homogeneity of variances. Student's $t$ test for independent samples $(p<0.05)$ was applied to assess whether statistically significant differences existed in abundances between sites. The abundance of recruits (of less than 1-mm long) and individuals (of more than 1-mm long) were analyzed separately. Relationships of the density of recruits with environmental variables were analyzed at each site by means of Pearson's correlation (r) analysis (Zar 1996).

A non-parametric multivariate analysis was applied to simultaneously consider all environmental variables that could potentially influence the biological data. For this statistical procedure, the Relationship Evaluation (RELATE) and Biota-Environment (BIOENV) routines in the PRIMER v5.2.9 package (Clarke and Warwick 2001) were applied. Individuals of greater than $1 \mathrm{~mm}$, individuals of less than $1 \mathrm{~mm}$ (recruits), and total individuals were analyzed separately. All physical and chemical variables of the water were included in the analysis. The Bray-Curtis similarity of samples and the standardized Euclidean distance of environmental variables were compared by RELATE, using the Spearman's rank correlation $\left(r_{\mathrm{s}}\right)$. This comparison provides a significance test that is equivalent to the Mantel-type method (Clarke and Warwick 2001).
The significance of the relationships was based on 999 random permutations of the data. A coefficient value $\left(r_{\mathrm{s}}\right)$ of close to 0 implies that there is no relation between the two similarity matrices, while a value close to 1 indicates a relation among the sample and variable matrices. The BIOENV routine (Clarke and Ainsworth 1993) was used to determine which variable or combination of variables best explained variations in the biological data, using rank correlation $\left(r_{\mathrm{s}}\right)$ values.

The Kolmogorov-Smirnov two-sample (K-S) test was applied to independent samples $(p<0.05)$ to compare the size frequency distribution of individuals between sites. This analysis was performed with the STATISTICA 6.0 software.

The shell growth parameters of L. fortunei populations were calculated by means of the von Bertalanffy growth function (VBGF). According to the modal progression method, age was assigned to each mode (cohort), and growth parameters were estimated by the iterative procedure proposed by Pauly (1984), with recruits (of less than 1-mm long) being excluded from the analysis. According to this function of generalized growth in length:

$$
L t=L_{\mathrm{inf}}\left(1-e^{-k\left(t-t_{o}\right)}\right)
$$

where $L_{t}$ is the average length $(\mathrm{mm})$ at time $t, L_{\text {inf }}$ is the maximum asymptotic length $(\mathrm{mm}), k$ is a constant that indicates the growth rate at which the $L_{\mathrm{inf}}$ is approached, $t_{0}$ is the time at which growth starts (the hypothetical zero length), and $t$ is time, the independent variable. Previously, this equation (VBGF) was successfully used to describe growth parameters of mussels (Evgenidou and Valiela, 2002, Maroñas et al. 2003).

\section{Results and discussion \\ Results \\ Environmental variables}

Water temperatures (Figure 2A) at Bagliardi Beach and Punta Indio varied according to the season, reaching maxima of $27.9^{\circ} \mathrm{C}$ and $28.6^{\circ} \mathrm{C}$ in December and passing through minima of $10.7^{\circ} \mathrm{C}$ in July and $8.5^{\circ} \mathrm{C}$ in June, with average values of $20.1^{\circ} \mathrm{C} \pm 5.3^{\circ} \mathrm{C}$ and $19.8^{\circ} \mathrm{C} \pm 6.6^{\circ} \mathrm{C}$, respectively. The $\mathrm{pH}$ was slightly alkaline at Bagliardi Beach $(7.8 \pm 0.4)$ and more so at Punta Indio $(8.4 \pm 0.3)$. TDS (Figure 2B) at Punta Indio $(930 \pm 911 \mathrm{mg} / \mathrm{L})$ were higher than those at Bagliardi Beach $(251 \pm 80 \mathrm{mg} / \mathrm{L})$. The conductivity (Figure $2 \mathrm{C}$ ) showed considerable differences between sites: at Bagliardi Beach, the minimum (193 $\mu \mathrm{S} / \mathrm{cm}$ in November) and maximum $(1560 \mu \mathrm{S} / \mathrm{cm}$ in September) occurred without substantial monthly variations $(605 \pm 344 \mu \mathrm{S} / \mathrm{cm})$, whereas at Punta Indio, the minimum (327 $\mu \mathrm{S} / \mathrm{cm}$ in June) and maximum $(5,770 \mu \mathrm{S} / \mathrm{cm}$ in $\mathrm{March})$ were accompanied by wide 


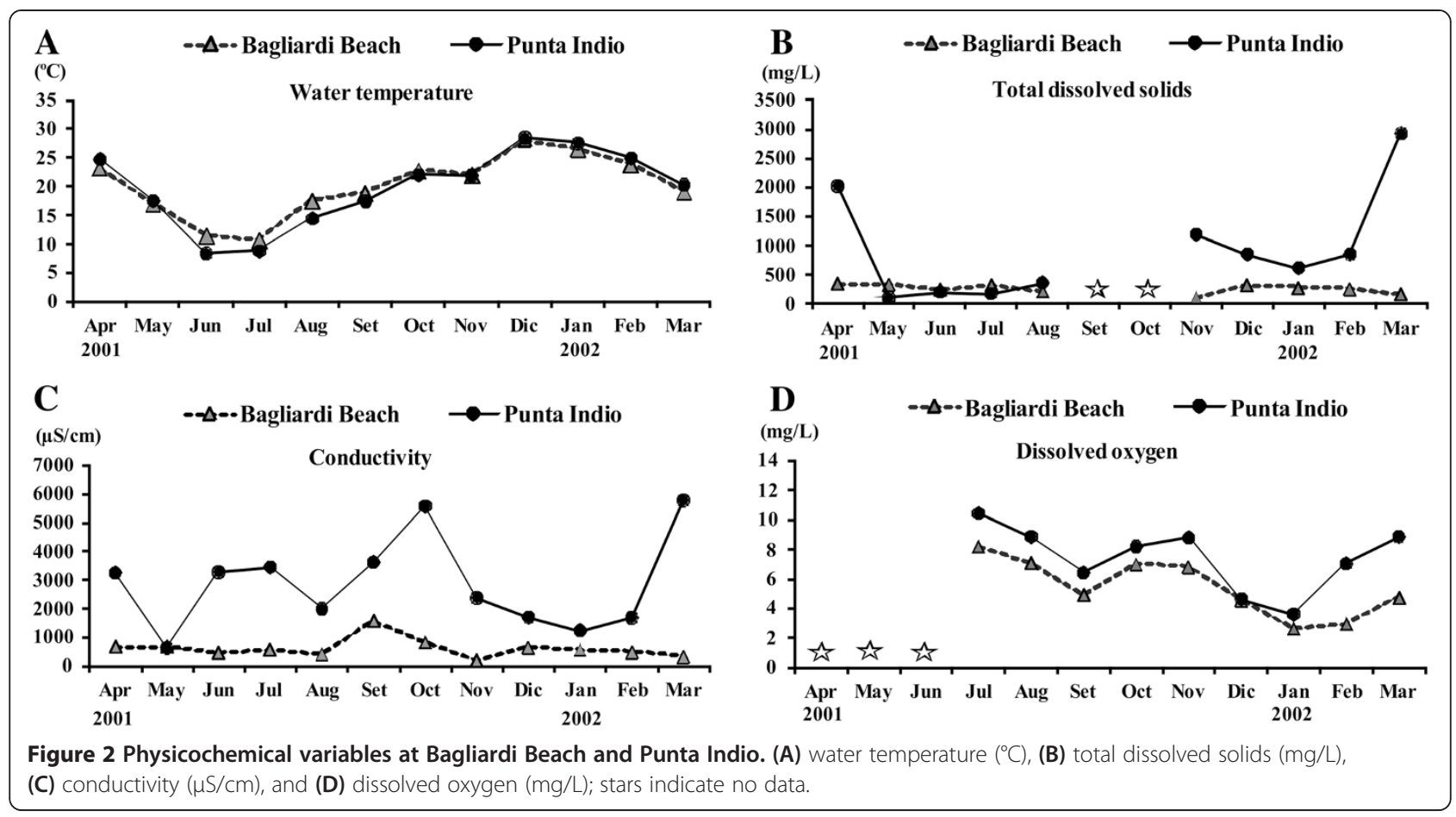

monthly fluctuations $(2,370 \pm 1,860 \mu \mathrm{S} / \mathrm{cm})$. The $\mathrm{DO}$ concentration (Figure 2D) was lower at Bagliardi Beach $(5.42 \pm 1.95 \mathrm{mg} / \mathrm{L})$ than at Punta Indio $(7.43 \pm 2.21 \mathrm{mg} / \mathrm{L})$, but both sites showed similar monthly variations throughout the year; DO saturation likewise exhibited a similar evenness at the two beaches $(58.6 \% \pm 17.6 \%$ and $78.0 \% \pm 17.0 \%$, respectively).

\section{Abundance and size structure}

The abundance of adults (individuals of greater $1 \mathrm{~mm}$ in length) at Bagliardi Beach $\left(42,300 \pm 9,600\right.$ ind. $\left./ \mathrm{m}^{2}\right)$ was much higher than that at Punta Indio $(16,700 \pm$ 2,750 ind. $/ \mathrm{m}^{2}$ ) during all months of the year (Figure $3 \mathrm{~A}$ ), and this difference between the 2 sites was significant (Student $t$-test -.05 $_{(2), 11}=10.4$ ).

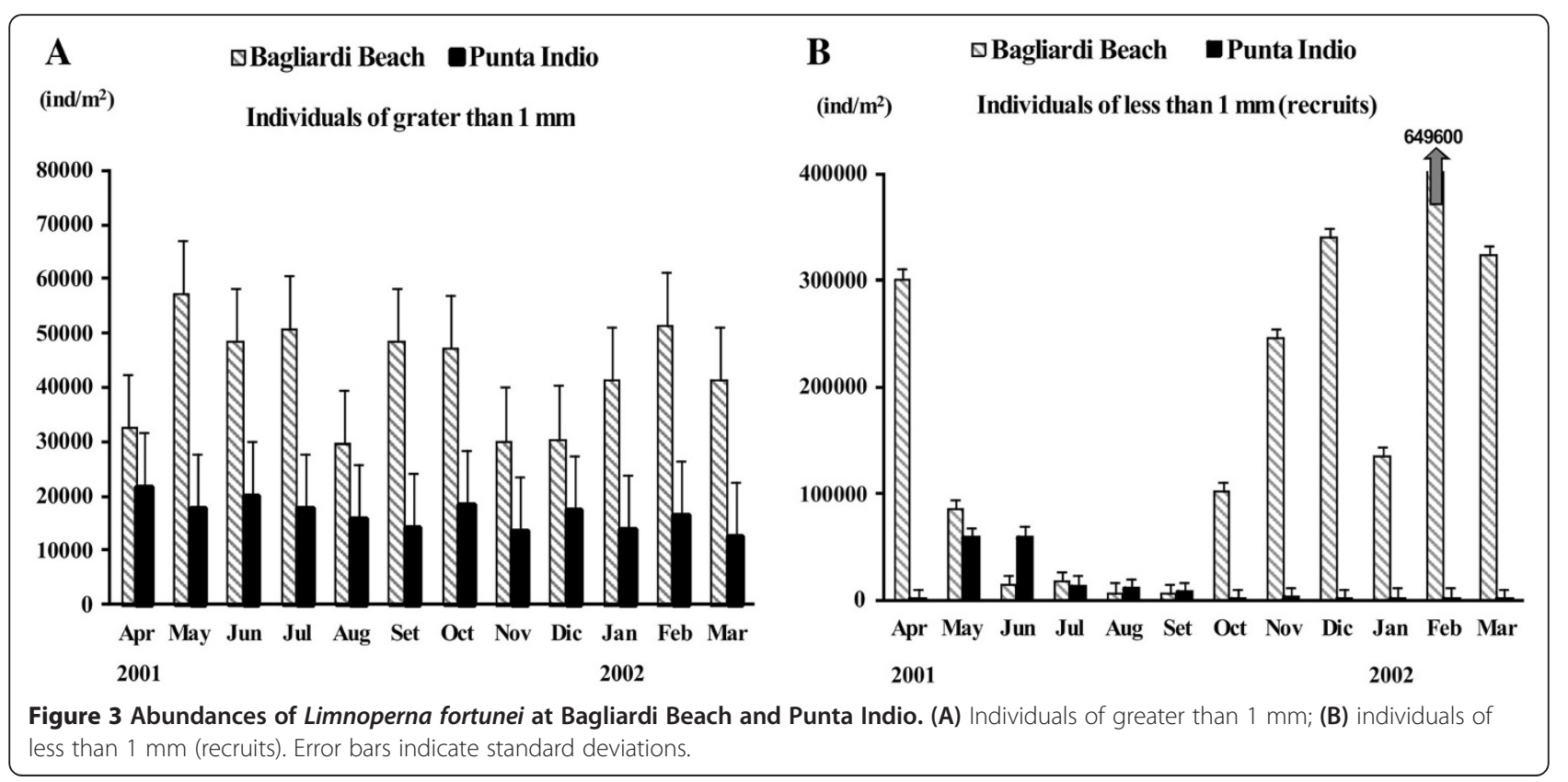


Abundances of recruits (individuals of less than $1 \mathrm{~mm}$ in length) also significantly differed $\left(t\right.$-test ${ }_{0.05}$ (2),11 $=$ 3.32) between sites. Recruits appeared in all samples at Bagliardi Beach $\left(185,000 \pm 195,000\right.$ ind. $\left./ \mathrm{m}^{2}\right)$. At this site, the increase in recruits was linked to elevated temperatures in spring and summer (i.e., mid-September to midMarch; see below). Three principal abundance peaks (December, February, and March to April) were recorded at greater 300,000 ind. $/ \mathrm{m}^{2}$. A subsequent decrease in the density of recruits was linked to low winter temperatures (from May to June through August; Figures 2A and $3 \mathrm{~B})$. In general, changes in recruit abundances throughout the year were highly positively correlated with water temperature $(r=0.667, p<0.05)$ but were only mildly correlated with the other environmental variables (pH $r=-0.22$, conductivity $r=-0.334$, TDS $r=-0.121$, DO $r=-0.561$, and oxygen saturation $r=-0.414$; all $p>0.05)$. Relative to the above values for Bagliardi Beach, Punta Indio had a far lower abundance of recruits $\left(13,200 \pm 22,100\right.$ ind. $\left./ \mathrm{m}^{2}\right)$. Late autumn (April to June) was the only season with just over 59,000 ind. $/ \mathrm{m}^{2}$ of recruits there (Figure 3B); June also concurrently exhibited the lowest conductivity value $(327 \mu \mathrm{S} / \mathrm{cm})$. In contrast, the lowest abundances of recruits (229 and $457 \mathrm{ind} . / \mathrm{m}^{2}$ ) in late summer (March) and spring (October), respectively, coincided with maximum values of conductivity (5770 $\mathrm{\mu S} / \mathrm{cm}$; Figures $2 \mathrm{C}$ and $3 \mathrm{~B}$ ). TDS, conductivity, and temperature were highly negatively correlated with the abundance of recruits (TDS $r=-0.862$, conductivity $r=-0.755$, and temperature $r=-0.718$; all $p<0.05)$; while $\mathrm{pH}$ was positively correlated $(r=0.65, p<0.05)$.
The remaining physicochemical variables were not correlated (DO $r=0.427$, and oxygen saturation $r=-0.119$; both $p>0.05)$.

Bagliardi Beach had smaller adult specimens (mean shell lengths of 8.02 to $12.7 \mathrm{~mm}$ ) than Punta Indio (15.6 to $19.5 \mathrm{~mm}$; Figure 4). Size frequency distributions (individuals of greater than $1 \mathrm{~mm}$ ) of L. fortunei significantly differed (K-S two-sample test, $p<0.05$ ) between the two sites.

\section{RELATE and BIOENV analyses}

Using the RELATE routine between the standardized Euclidian distance matrix of physicochemical variables and the Bray-Curtis similarity matrix of mussel abundances at Bagliardi Beach, the statistical analysis revealed no significant correlation for total individuals $\left(r_{s}=0.036\right.$, $p>0.36)$, individuals of greater than $1 \mathrm{~mm}\left(r_{s}=0.071\right.$, $p>0.3$ ), or recruits or individuals of less than $1 \mathrm{~mm}$ $\left(r_{s}=0.04, p>0.36\right)$. At Punta Indio, the RELATE analysis detected a strong relationship between matrices for total individuals $\left(r_{s}=0.658, p<0.001\right)$ and individuals of less than $1 \mathrm{~mm}$ (recruits) $\left(r_{s}=0.578, p<0.001\right)$. The analysis showed no significant correlation for individuals of greater than $1 \mathrm{~mm}\left(r_{s}=0.072, p>0.29\right)$.

At Punta Indio, the BIOENV analysis indicated a strong influence in the combination of environmental variables (temperature, TDS, and oxygen saturation) for total individuals and recruits or individuals of less than $1 \mathrm{~mm}$ ( $r_{s}=0.684$ and 0.616, respectively). At Bagliardi Beach, the relationships between biological and environmental variables showed low rank correlations (Table 1).

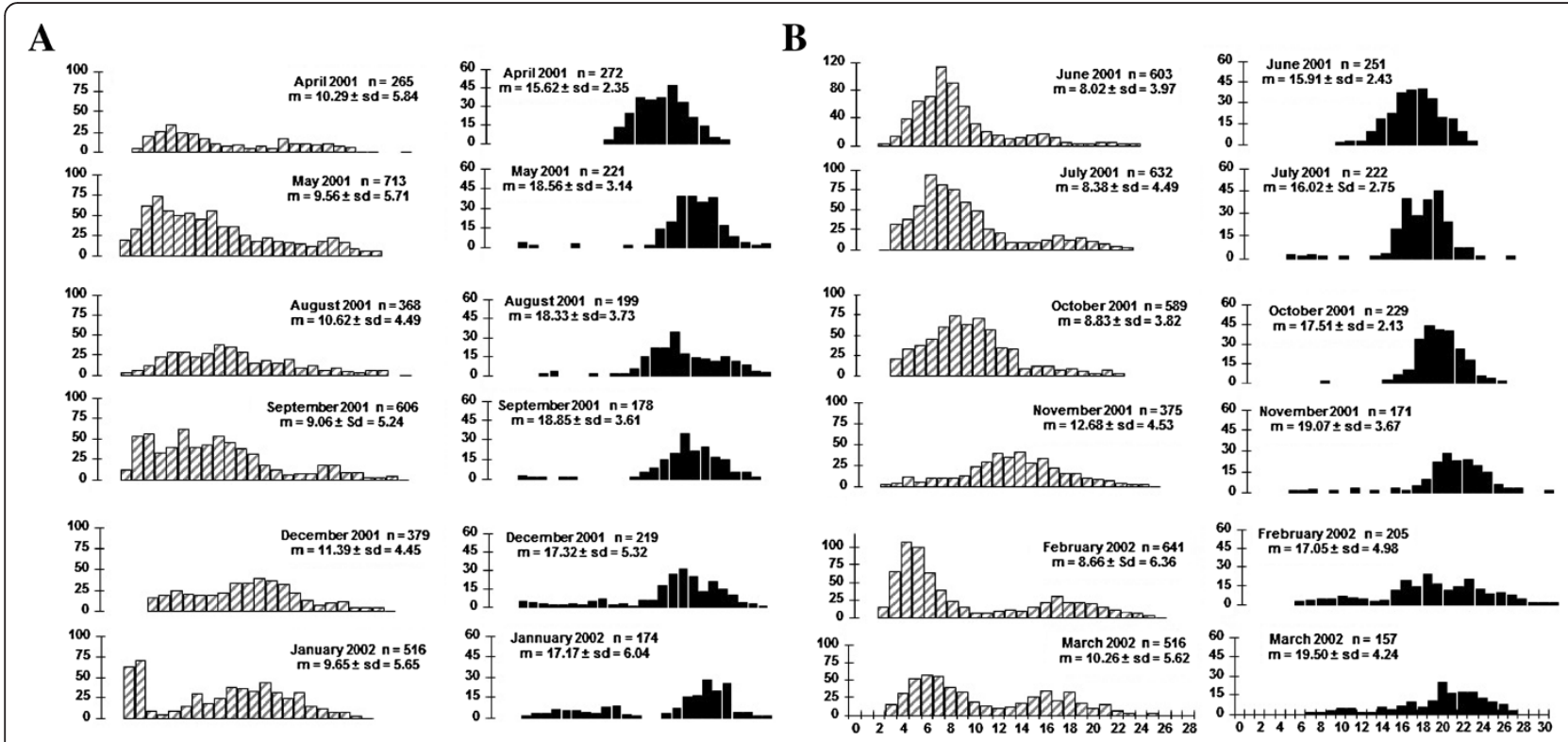

Figure 4 Size frequency distribution of Limnoperna fortunei for 12 months. (A) Bagliardi Beach; (B) Punta Indio. $n$, number of individuals of greater than $1 \mathrm{~mm}$; m, mean; sd, standard deviation (at intervals of $1 \mathrm{~mm}$ ). 
Table 1 Best results from the BIOENV analysis based on Spearman's rank correlations $\left(r_{s}\right)$

\begin{tabular}{|c|c|c|c|c|}
\hline \multirow[t]{2}{*}{ Biological matrix } & \multicolumn{2}{|c|}{ Bagliardi beach } & \multicolumn{2}{|c|}{ Punta Indio } \\
\hline & $r_{s}$ & Subset of variables & $r_{s}$ & Subset of variables \\
\hline \multirow[t]{3}{*}{ Total individuals } & 0.385 & $\mathrm{~T}$ & $0.684^{*}$ & T, TDS \\
\hline & 0.291 & T, Cond & $0.681^{*}$ & $\mathrm{~T}, \mathrm{TDS}, \% \mathrm{O}$ \\
\hline & 0.255 & T, Cond, DO & $0.669^{*}$ & $\mathrm{pH}, \mathrm{T}, \mathrm{TDS}, \% \mathrm{O}, \mathrm{DO}$ \\
\hline \multirow[t]{3}{*}{ Individuals of greater than $1 \mathrm{~mm}$} & 0.095 & $\mathrm{pH}, \mathrm{T}$, Cond, TDS & 0.138 & pH TDS \\
\hline & 0.093 & Cond & 0.131 & $\mathrm{pH}$, Cond \\
\hline & 0.092 & $\mathrm{pH}$, Cond, TDS & 0.123 & TDS \\
\hline \multirow[t]{3}{*}{ Individuals of less than $1 \mathrm{~mm}$ (recruits) } & 0.420 & T & $0.616^{*}$ & $\mathrm{~T}, \mathrm{TDS}, \% \mathrm{O}$ \\
\hline & 0.333 & $\mathrm{~T}$, Cond & $0.615^{*}$ & T, TDS \\
\hline & 0.279 & T, Cond, DO & $0.599^{*}$ & T,TDS, DO \\
\hline
\end{tabular}

Biological and physicochemical variables: $\mathrm{pH}$ power of Hydrogen, $T$ temperature, Cond conductivity, TDS total dissolved solids, \%O oxygen saturation, and DO dissolved oxygen; * Significant at $p \leq 0.05$.

\section{Individual growth}

L. fortunei populations were formed of several cohorts, particularly at Bagliardi Beach. During the year, this site had a large overlap of recruits that made separation into different size groups and identification of cohorts difficult. Three principal cohorts were, however, recognized at both sites. Figure 5 and Table 2 show growth curves for each cohort and corresponding growth parameters $\left(t_{0}, k\right.$, and $\left.L_{\text {inf }}\right)$ from the von Bertalanffy growth function. Individuals grew faster during the early period of life, reaching 18 to $20 \mathrm{~mm}$ of length in the first year. Thereafter, the growth rate became slower until the maximum length $\left(L_{\mathrm{inf}}=30 \mathrm{~mm}\right)$ was reached in less than 3 years.

\section{Discussion}

Abundance and size

Abundances of individuals of greater than $1 \mathrm{~mm}$ in size have shown large variations at Bagliardi Beach since the golden mussel's first settlement in 1991. That subpopulation increased from 4 to 5 ind./ $\mathrm{m}^{2}$ in 1991 to over 150,000 ind./ $\mathrm{m}^{2}$ in 1995 but then decreased to $40,000 \mathrm{ind} . / \mathrm{m}^{2}$ in 2001 (Darrigran et al. 2003). According to those authors and results from the present study (at 40,300 \pm 9600 ind. $/ \mathrm{m}^{2}$, after excluding recruits), the density of $L$. fortunei has stabilized after the processes of invasion and colonization. A similar pattern occurred with the invasive mussel D. polymorpha in certain freshwater bodies of Europe and North America (Burlakova et al. 2006).

The population of the golden mussel at the southern edge of its distribution range (Punta Indio) was predominately formed by larger individuals with a lower abundance than at the more-northerly site (Bagliardi Beach). The length of time exposed to air is a major condition governing differences in densities and sizes of mussels (Ricciardi et al. 1995). These considerations suggested the hypothesis that at Punta Indio, the golden mussel might spend less time on average exposed to the air than at Bagliardi Beach, because at the former site, boulders are more scattered and on a gentler slope than at the latter, and the mean low water along that southern border is a bit lower $(0.48 \mathrm{~m})$ than at the more-northerly site $(0.52 \mathrm{~m})$.
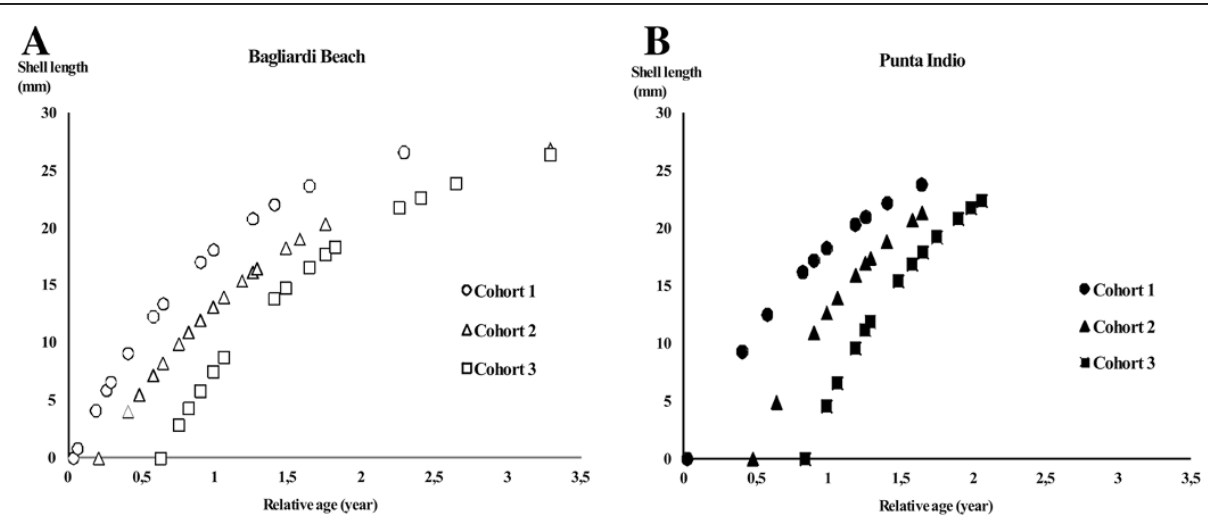

Figure 5 Growth curves of shell length of $L$. fortunei. (A) Bagliardi Beach; (B) Punta Indio. 
Table 2 Parameters of growth curves for $L$. fortunei (VBGF method)

\begin{tabular}{|c|c|c|c|c|c|c|c|}
\hline Site & Cohort & $t_{o}$ & $L_{\text {inf }}(\mathrm{mm})$ & $k$ & $R^{2}$ & $\begin{array}{l}\text { First-year } \\
\text { growth }\end{array}$ & $\begin{array}{c}\text { Suggested } \\
\text { longevity (years) }\end{array}$ \\
\hline \multirow[t]{3}{*}{ Bagliardi Beach (Río de la Plata Estuary, Argentina) } & 1 & 0.030 (January 2002) & & 0.969 & 0.98 & & \\
\hline & 2 & 0.205 (March 2001) & 30 & 0.738 & 0.98 & 18 to 20 & $<3$ \\
\hline & 3 & 0.626 (August 2001) & & 0.794 & 0.97 & & \\
\hline \multirow[t]{3}{*}{ Punta Indio (Río de la Plata Estuary, Argentina) } & 1 & 0.023 (January 2002) & & 0.978 & 0.93 & & \\
\hline & 2 & 0.474 (June 2001) & & 1.069 & 0.91 & 18 to 20 & $<3$ \\
\hline & 3 & 0.841 (November 2001) & 30 & 1.127 & 0.97 & & \\
\hline Atucha I (Paraná de las Palmas River, Argentina) ${ }^{a}$ & 1 (follow-up) & - (January 1998) & 35 & 1 & - & 20 & 3 \\
\hline \multirow[t]{3}{*}{ Bagliardi Beach (Río de la Plata Estuary, Argentina) ${ }^{b}$} & 1 & -0.071 (December 1993) & & 0.337 & 0.99 & & \\
\hline & 2 & 0.097 (February 1994) & 36 & 0.340 & 0.98 & 10 & 3.2 \\
\hline & 3 & 0.513 (July 1994) & & 0.376 & 0.94 & & \\
\hline
\end{tabular}

$t_{0}$, initial time; $L_{\text {inf, }}$ first-year growth; $k$, growth rate as determined from the growth curves of Figure 5 ; $R^{2}$, correlation coefficient from the least-squares regression curves; VBGF, von Bertalanffy growth function for generalized growth in length; VBSGF, von-Bertalanffy seasonal growth function for seasonally oscillating growth in length. ${ }^{a}$ VBSGF method (Boltovskoy and Cataldo 1999), ${ }^{b}$ Maroñas et al. 2003.

L. fortunei is well tolerant of air exposure: larger individuals (of 15 to $27 \mathrm{~mm}$ ) resist desiccation for a longer time $(108 \mathrm{~h}$ ) than smaller ones (up to $6 \mathrm{~mm}$; $72 \mathrm{~h}$; Montalto and Ezcurra de Drago 2003). According to Darrigran et al. (2004), survival of the golden mussel upon air exposure improves with an increase in the relative humidity. The stacked boulders at Bagliardi Beach containing a high density of golden-mussel aggregates furthermore facilitate the retention of humidity and provide a refuge for a high level of recruitment (i.e., enhanced recruit survival) during low tides. According to Sardiña et al. (2009), the density of L. fortunei conspecific adults in the Carapachay River in the lower Paraná-River delta (Argentina) had strong positive effects on the number and growth of newly settled recruits.

At the other sampling site, the low abundance of adults provided poorer shelter for recruitment and retarded desiccation with less efficiency. Those fewer juveniles were able to withstand that stress threshold of air exposure thus constituted the survivors that were recorded. In general, larger-sized mussels are found on shores exposed to waves than on sheltered ones (McQuaid and Lindsay 2000). This principle may likewise apply to Punta Indio, where waves at high tide are generally higher than those at Bagliardi Beach because of the cape's proximity to the river's external zone and dynamics of the transition between estuarine and freshwater areas.

Finally, no other sessile species inhabited the hard substrates at Bagliardi Beach, whereas at Punta Indio, B. improvisus appeared at an extremely low density with an overlapping distribution (also see Orensanz et al. 2002). Interspecific competition for space is not a biologic circumstance; however, it does regulate the abundance and size classes of the golden mussel. The effect of other biologic influences, e.g., predation by fish (Penchaszadeh et al. 2000), could also be excluded as a potential explanation for the observed differences in abundance between the two sites.

\section{Recruitment}

The length frequency distribution and the high abundance of recruits at Bagliardi Beach indicated that $L$. fortunei continuously reproduced throughout the year, with two strong spawning periods peaking in December and February. Temperature is the main environmental condition controlling gonadal spawning of the golden mussel by means of variations in and extension of the reproductive cycle in a temperate climatic region, such as at Río de la Plata Estuary (Darrigran et al. 1999; Cataldo and Boltovskoy 2000). Darrigran et al. (2003) reported two significant peaks in gonadal growth of the golden mussel occurring toward the end of winter (late August and early September) and at the beginning of spring (October and early November) at temperatures of greater than or equal to $20^{\circ} \mathrm{C}$. One further peak, longer and more pronounced than the previous ones, takes place in the latter part of the summer (February and March). According to Darrigran et al. (2003), gametes are released when the water temperature exceeds $16^{\circ} \mathrm{C}$. From observations of the occurrence and abundance of recruits in conjunction with temperatures registered in the present study, the spawning of L. fortunei in these locations would appear to take place at a lower temperature than was indicated by those authors. Recruits were able to survive at the low temperatures registered in the winter at Bagliardi Beach $\left(10.7^{\circ} \mathrm{C}\right)$. In a nuclear power plant at Paraná de las Palmas, Paraná River, Argentina, which is farther north than Bagliardi Beach, the golden mussel also exhibited continuous reproduction between the months of August and April, although larval production decreased thereafter during the lowest temperatures from May through July (Cataldo and Boltovskoy 2000). 
Only a few small-sized individuals and a lower abundance of recruits were recorded at Punta Indio. Although this site had the same annual temperature cycle as Bagliardi Beach, with both being in the same temperate climate, Punta Indio exhibited different patterns of recruitment. Temperature per se, therefore, cannot be cited as the principal determinant of spawning. The multivariate RELATE and BIOENV analyses provided additional discussion of this. The analyses demonstrated that at Punta Indio, there was a significant relationship between the abundance of recruits and the combination of temperature with other physicochemical variables, such as TDS and oxygen saturation percentage. This indicates that a single environmental variable alone is not sufficiently explanatory.

Other physicochemical variables such as salinity must be regulating the presence, survival, and density of recruits. The proximity of Punta Indio to the external (estuarine) zone of the Río de la Plata causes relevant variations in conductivity and TDS (Guerrero et al. 1997; Wells and Daborn 1997), which would necessarily produce instability for recruiting.

Recruitment may also be linked to the retreat of the turbidity front that characterizes the limit between the intermediate and external zones of the estuary. There, fresh water flows into the sea on the surface, while a socalled salt-wedge regime, or underlayer of denser water, runs in a countercurrent along the bottom from the platform (Guerrero et al. 1997; Mianzan et al. 2001). According to Oliveira et al. (2011) in the Miranda River (Brazil), the combination of a high concentration of suspended sediments (high inorganic turbidity), low food availability, and elevated water velocity might constitute limiting conditions for larval settlement of $L$. fortunei. The same dynamics occur in zebra mussel populations of the Mississippi River system, particularly when those conditions are combined with high temperatures (Allen et al. 1999).

At Punta Indio, the principal peak in abundance of recruits occurred during late autumn and early winter. Recruitment may in fact depend more on the input of larvae from upstream rather than on larval production by local individuals, when the output of fresh water into the external zone is favored by a north-to-south current. The Río de la Plata Estuary receives a discharge of $15,000 \mathrm{~m}^{3} / \mathrm{s}$ of fresh water from the Paraná and Uruguay Rivers during the dry season (summer) and of $26,000 \mathrm{~m}^{3} / \mathrm{s}$ during the wet season (autumn and winter). This freshwater discharge rises sharply in May, peaking between July and September, and then drops to minimum values in December and January (Guerrero et al. 1997).

Hard substrates are grouped together and are scarce along the coastline of the Río de la Plata Estuary, i.e., they show discrete and disparate arrangements, and this characteristic results in discontinuities in the availability of rocks and stones for settlement and distribution of golden mussels. Such features of the estuary in which this species is nevertheless successfully populating in conjunction with the following four observations suggest the hypothesis that the golden mussel is characterized by a metapopulational structure (see Hanski 1999): (a) the sessile lifestyle of adults and planktonic larval stages, (b) the high density of recruits at the northern site (Bagliardi Beach), (c) the low abundance of recruits at the southern site (Punta Indio), and (d) the likely dispersal of larvae from north to south, following the course of the estuary with subsequent colonization of empty substrates.

\section{Individual growth}

Similarities and differences between these data and results found by Boltovskoy and Cataldo (1999) and Maroñas et al. (2003) for the Río de la Plata Estuary are summarized in Table 2. In agreement with Maroñas et al. (2003), three principal annual cohorts were found at Bagliardi Beach that were directly related to the major spawning peaks observed by Darrigran et al. (1999) at the same site. Other cohorts were observed overlapping the main growth plateaus but were less significant. This overlap results from the continuous reproduction and high abundance of recruits recorded. Growth rates were similar to those estimated by Boltovskoy and Cataldo (1999), and in keeping with those authors, individuals were seen to have grown approximately $20 \mathrm{~mm}$ in length during the first year, $10 \mathrm{~mm}$ more than suggested by Maroñas et al. (2003). Despite low temperatures in winter, a condition which could lead to stunting, the data did not reflect a significant decline in growth rates among sampling dates. The data better fit the VBGF model of generalized growth in length than one of a von Bertalanffy seasonal growth function (VBSGF) in length. Effects of both high and low extremes of temperatures, however, were evident in growth rates indicated by the curves fitted for each site. The highest growth rates corresponded to the initial time point close to spring. Differences between predicted and observed shell lengths were very low for each cohort, as shown by the high correlation coefficients obtained. In Lake Ohshio (Japan), Nakano et al. (2011) found that the growth rate of $L$. fortunei slightly increased in autumn after recruitment, approached 0 in the winter, and then greatly increased in summer; and those growth kinetics were strongly correlated with water temperature.

Food supply (e.g., plankton) is considered the most critical parameter controlling mussel growth; although temperature, salinity, air exposure, water depth, and population density are also highly influential (Seed and Suchanek 1992). In the Río de la Plata Estuary, along 
with the presence of detritus, the abundance, biomass, and composition of phytoplankton vary along the coast from the north (with greater amounts of Chlorophyceae and Cyanophyceae) to the south (with a prevalence of euryhaline diatoms; Gómez et al. 2004). The different quality and quantity of food for L. fortunei between the two sites may have produced differences in growth and reproduction. In a mesocosm experiment with $L$. fortunei conducted by Rojas Molina et al. (2012), the development of the golden mussel was associated with significant declines in abundances of phytoplankton and zooplankton, due to the high filtration rate, and with a decrease in suspended particulate matter (suspended solids and turbidity). This variable should be considered in the growth of mussels at Punta Indio since this site is near the turbidity front of the Río de la Plata Estuary, as mentioned above.

Other conditions that can affect growth rates are the duration of air exposure and the degree of movement of the water. Although these environmental variables were not measured, the slightly lower growth rates at Bagliardi Beach are perhaps related to a shorter average time of submersion along with a lower degree of wave action than at Punta Indio. Water movement was accordingly shown to have a positive influence on the growth rate of other species of mussels such as $D$. polymorpha (Karatayev et al. 2006).

Growth rates may also be directly related to the aggregation density and reduction in space (interspecific competition): the lower density of mussels at Punta Indio could facilitate higher growth rates than in the overcrowded habitat at Bagliardi Beach. According to Schurink and Griffiths (1993), increased physical contact between mussels creates more mantle retraction and valve closures, the effects of which would result in less time for feeding and growth.

\section{Conclusion}

In conclusion, this work provides specific information that complements our present knowledge of the ecology of this invasive mollusk, although further studies will be essential to gain an understanding of the population dynamics (e.g., processes of recruitment and dispersal) and the way in which the golden mussel reacts to stressful conditions.

\section{Competing interests}

The author has no competing interests.

\footnotetext{
Acknowledgments

This work was supported by a grant from the Comisión de Investigaciones Científicas de la Provincia de Buenos Aires (CIC), Argentina. I am very grateful to the anonymous reviewers for their suggestions and critical comments for improving the manuscript. Special thanks go to Dr. A. Spaccesi for his valuable technical assistance in the field. I am indebted to J. Marciano for kindly helping with the English writing of the manuscript and to Dr. D.F. Haggerty, a retired career investigator and native English speaker, for editing the final version. This is scientific contribution no. 838 of the Instituto de Limnología "Dr. R. Ringuelet".
}

Received: 19 March 2012 Accepted: 11 January 2013

Published: 30 July 2013

\section{References}

Allen YC, Thompson BA, Ramcharan CW (1999) Growth and mortality rates of the zebra mussel, Dreissena polymorpha, in the lower Mississippi River. Can J Fish Aquat Sci 56:748-759

APHA (1998) Standard methods for examination of water and wastewater, 20th edition. American Public Health Association (APHA), Washington, DC, p 1325. pp

Bazán JM, Arriaga E (1993) El Río de la Plata, ¿un sistema fluvio-marítimo frágil?: acercamiento a una definición de la calidad de las aguas. In: Boltovskoy A, López H (ed) Conferences on limnology. Instituto de Limnología "Dr RA Ringuelet, La Plata, Argentina, pp 71-82. in Spanish with English abstract

Boltovskoy D, Cataldo D (1999) Population dynamics of Limnoperna fortunei, an invasive fouling mollusc, in the Lower Paraná River (Argentina). Biofouling 380:153-163

Boltovskoy D, Correa N, Cataldo D, Sylvester F (2006) Dispersion and ecological impact of the invasive freshwater bivalve Limnoperna fortunei in the Río de la Plata watershed and beyond. Biol Invasions 8:947-963

Bownes SJ, McQuaid CD (2006) Will the invasive mussel Mytilus galloprovincialis Lamarck replace the indigenous Perna perna $\mathrm{L}$. on the south coast of South Africa? J Exp Mar Biol Ecol 338:140-151

Burlakova LE, Karatayev AY, Padilla DK (2006) Changes in the distribution and abundance of Dreissena polymorpha within lakes through time. Hydrobiologia 571:133-146

Cataldo DH, Boltovskoy D (2000) Yearly reproductive activity of Limnoperna fortunei (Bivalvia) as inferred from the occurrence of its larvae in the plankton of the lower Parana River and the Rio de la Plata Estuary (Argentina). Aquat Ecol 34:307-317

Cataldo DH, Boltovskoy D, Pose M (2003) Toxicity of chlorine and three nonoxidizing molluscicides to the invasive pest mussel Limnoperna fortunei. J Am Water Works Assoc 95:66-78

Clarke KR, Ainsworth M (1993) A method of linking multivariate community structure to environmental variables. Mar Ecol Progr Ser 92:205-219

Clarke KR, Warwick RM (2001) Change in marine communities: an approach to statistical analysis and interpretation. PRIMER-E, Plymouth, UK

Darrigran G, Penchaszadeh P, Damborenea MC (1999) The reproductive cycle of Limnoperna fortunei (Dunker 1857) Bivalvia Mytilidae from Neotropical temperature locality. J Shellfish Res 18:2361-2365

Darrigran G, Damborenea MC, Penchaszadeh P, Taraborelli C (2003) Adjustments of Limnoperna fortunei (Bivalvia: Mytilidae) after ten years of invasion in the Americas. J Shellfish Res 22:141-146

Darrigran GA, Maroñas ME, Colautti DC (2004) Air exposure as control mechanism for the golden mussel, Limnoperna fortunei, (Bivalvia: Mytilidae). J Freshw Ecol 19:46-464

Evgenidou A, Valiela I (2002) Response of growth and density of a population of Geukensia demissa to land-derived nitrogen loading, in Waquoit Bay, Massachusetts. Estuar Coast Shelf Sci 55:125-138

Gómez N, Hualde P, Licursi M, Bauer D (2004) Spring phytoplankton of Río de la Plata: a temperate estuary of South America. Estuar Coast Shelf Sci 61:301-309

Grosholz ED (2002) Ecological and evolutionary consequences of coastal invasions. Trends Ecol Evol 17:22-27

Guerrero RA, Acha EM, Framiña MB, Lasta CA (1997) Physical oceanography of the Río de la Plata Estuary, Argentina. Cont Shelf Res 17:727-742

Hanski I (1999) Metapopulation ecology. Oxford Univ. Press, Oxford, UK, p 328

Karatayev AY, Burlakova LE, Padilla DK (2006) Growth rate and longevity of Dreissena polymorpha (Pallas): a review and recommendations for future study. J Shellfish Res 25:23-32

Magara Y, Matsui Y, Goto Y, Yuasa A (2001) Invasion of the non-indigenous nuisance mussel, Limnoperna fortunei, into water supply facilities in Japan. J Water Supply Res T 50:113-124

Mansur MC, Pinhiero C, dos Santos G, Darrigran IH, Calli C, Rossoni Cardoso F (2003) Primeros dados quali-quantitativos do mexilhãodourado, Limnoperna fortunei (Dunker), no Delta do Jacuí, no Lago Gauíba e na Laguna dos Patos, Río Grande do Sul, Brasil e alguns aspectos de sua invasão no novo ambiente. Rev Bras Zool 20:75-84

Maroñas ME, Darrigran G, Sendra ED, Breckon G (2003) Shell growth of the golden mussel Limnoperna fortunei (Dunker, 1857) (Mytilidae) in the Río de la Plata, Argentina. Hydrobiologia 495:41-45 
McQuaid CD, Lindsay TL (2000) Effect of wave exposure on growth and mortality rates of the mussel Perna perna: bottom up regulation of intertidal populations. Mar Ecol Progr Ser 206:147-154

Mianzan H, Lasta C, Acha E, Guerrero R, Macchi G, Bremec C (2001) The Rio de la Plata Estuary, Argentina-Uruguay. In: Seeliger U, Kjerfve B (ed) Coastal marine ecosystems of Latin America. Ecological studies 144. Springer, Berlin, pp 185-204

Montalto L, de Drago IE (2003) Tolerance to desiccation of an invasive mussel Limnoperna fortunei (Dunker, 1857) (Bivalvia, Mytilidae), under experimental conditions. Hydrobiologia 498:161-167

Morton B (1973) Some aspects of the biology and functional morphology of feeding and digestion of Limnoperna fortunei (Dunker) (Bivalvia: Mytilacea). Malacologia 12:265-281

Morton B (1977) The populations dynamics of Limnoperna fortunei (Dunker, 1857) (Bivalvia: Mytilacea) in Plover Cove Reservoir, Hong Kong. Malacologia 16:165-182

Moyle PB, Light T (1996) Biological invasions of freshwater: empirical rules and assembly theory. Biol Conserv 78:149-161

Nakano D, Kobayashi T, Endo N, Sakaguchi I (2011) Growth rate and settlement of Limnoperna fortunei in a temperate reservoir. J Mollusc Stud 77:142-148

Oliveira MD, Calheiros DF, Jacobi CM, Hamilton SK (2011) Abiotic factors controlling the establishment and abundance of the invasive golden mussel Limnoperna fortunei. Biol Invasions 13:717-729

Orensanz JM, Schwindt E, Pastorino G, Bortolus A, Casas G, Darrigran G, et al. (2002) No longer the pristine confines of the world ocean: a survey of exotic marine species in the southwestern Atlantic. Biol Invasions 4:115-143

Pastorino G, Darrigran G, Martin SM, Lunaschi L (1993) Limnoperna fortunei (Dunker, 1857) (Mytilidae), nuevo bivalvo invasor en aguas del Río de la Plata. Neotropica 39:101-102 (in Spanish)

Pauly D (1984) Fish population in tropical waters. Manual for use with programme calculator ICLARM. Studies and Reviews 8, Manila, the Philippines, p 325

Penchaszadeh PE, Darrigran G, Angulo C, Averbuj A, Brogger M, Dogliotti A, Pirez N (2000) Predation of the invasive freshwater mussel Limnoperna fortunei (Dunker, 1857) (Mytilidae) by the fish Leporinus obtusidens Valenciennes, 1846 (Anostomidae) in the Río de la Plata, Argentina. J Shellfish Res 19:229-231

Ricciardi A, Serrouya R, Whoriskey FG (1995) Aerial exposure tolerance of zebra and quagga mussels (Bivalvia: Dreissenidae): implications for overland dispersal. Can J Fish Aquat Sci 52:470-477

Rojas Molina F, de Paggi SJ, Frau D (2012) Impacts of the invading golden mussel Limnoperna fortunei on zooplankton: a mesocosm experiment. Zool Stud 51:733-744

Sardiña P, Cataldo DH, Boltovskoy D (2009) Effects of conspecifics on settling juveniles of the invasive golden mussel, Limnoperna fortunei. Aquat Sci 71:479-486

Schurink CE, Griffiths CL (1993) Factors affecting relative rates of growth in 4 South African mussel species. Aquaculture 109:257-273

Seed R, Suchanek TH (1992) Population and community ecology of Mytilus. In: Gosling EM (ed) The mussel Mytilus: ecology, physiology, genetics and culture. Elsevier, Amsterdam, pp 87-169

SHN (2001) In: de Hidrografía Naval S (ed) Tablas de marea: Puertos de la República Argentina y algunos puertos de Brasil, Uruguay y Chile. Armada Argentina, República Argentina, p 504. in Spanish

Spaccesi FG, Rodrigues Capítulo A (2012) Benthic communities on hard substrates covered by Limnoperna fortunei Dunker (Bivalvia, Mytilidae) in a freshwater estuarine beach (Río de la Plata, Argentina). J Limnol 71:144-153

Stephenson TA, Stephenson A (1949) The universal features of zonation between tide-marks on rocky coasts. J Ecol 37:289-305

Suchanek TH, Geller JB, Kreiser BR, Mitton JB (1997) Zoogeographic distributions of the sibling species Mytilus galloprovincialis and M. trossulus (Bivalvia: Mytilidae) and their hybrids in the North Pacific. Biol Bull 193:187-194

Sylvester F, Boltovskoy D, Cataldo DH (2007) Fast response of freshwater consumers to a new trophic resource: predation on the recently introduced Asian bivalve Limnoperna fortunei in the lower Paraná River, South America. Aust Ecol 32:403-415

Vermeij GJ (1996) An agenda for invasion biology. Biol Conserv 78:3-9

Wasson K, Zabin CJ, Bedinger L, Diaz MC, Pearse JS (2001) Biological invasions of estuaries without international shipping: the importance of intraregional transport. Biol Conserv 102:143-153
Wells PG, Daborn GR (ed) (1997) The Río de la Plata. An environmental overview. An EcoPlata project background report. , Halifax, Nova Scotia, Canada, Dalhousie Univ

Wu JY, Wu YT, Li MC, Chiu YW, Liu MY, Liu LL (2011) Reproduction and juvenile growth of the invasive apple snails Pomacea canaliculata and $P$. scalaris (Gastropoda: Ampullariidae) in Taiwan. Zool Stud 50:61-68

Zar JH (1996) Biostatistical analysis, 3rd edition. Prentice Hall, Upper Saddle River, NJ, p 662

doi:10.1186/1810-522X-52-1

Cite this article as: Spaccesi: Abundance, recruitment, and shell growth of the exotic mussel Limnoperna fortunei in the Río de la Plata

(Argentina). Zoological Studies 2013 52:1.

\section{Submit your manuscript to a SpringerOpen ${ }^{\circ}$ journal and benefit from:}

- Convenient online submission

- Rigorous peer review

- Immediate publication on acceptance

- Open access: articles freely available online

- High visibility within the field

- Retaining the copyright to your article

Submit your next manuscript at springeropen.com 